\title{
HLA-DR52 Antibody Measurement
}

National Cancer Institute

\section{Source}

National Cancer Institute. HLA-DR52 Antibody Measurement. NCI Thesaurus. Code C128960.

The determination of the amount of HLA-DR52 antibody present in a sample. 